\title{
Green Method for Synthesis of Gold Nanoparticles Using Polyscias scutellaria Leaf Extract under UV Light and Their Catalytic Activity to Reduce Methylene Blue
}

\author{
Yoki Yulizar, Tresye Utari, Harits Atika Ariyanta, and Digha Maulina \\ Department of Chemistry, Faculty of Mathematics and Natural Sciences, Universitas Indonesia, Depok 16424, Indonesia \\ Correspondence should be addressed to Yoki Yulizar; yokiy@ui.ac.id
}

Received 9 February 2017; Accepted 19 September 2017; Published 28 November 2017

Academic Editor: Ilaria Fratoddi

Copyright (C) 2017 Yoki Yulizar et al. This is an open access article distributed under the Creative Commons Attribution License, which permits unrestricted use, distribution, and reproduction in any medium, provided the original work is properly cited.

\begin{abstract}
The aqueous fraction of Polyscias scutellaria leaf extract (PSE) has been used as a reducing agent and stabilizer in the green synthesis of gold nanoparticles (AuNPs). UV-Vis spectrophotometry, particle size analyzer (PSA), Fourier transform infrared (FTIR) spectroscopy, transmission electron microscopy-selected area electron diffraction (TEM-SAED), and X-ray diffraction (XRD) were used to characterize AuNPs. The AuNPs have a size of 5-20 nm and have a face centered cubic (fcc) crystal structure and are stable for 21 days. Phenolic compounds, which are secondary metabolites of PSE, act as an active compound to reduce Au ${ }^{3+}$ ion to $\mathrm{Au}^{0}$, as well as stabilize the AuNPs through their surface interaction with carbonyl and hydroxyl groups of phenols. AuNPs exhibit excellent catalytic activity for the reduction of methylene blue with $\mathrm{NaBH}_{4}$. The reduction of methylene blue using AuNPs catalysts is a pseudo-first-order reaction with a reduction rate constant $\left(k_{\mathrm{obs}}\right)$ of $0.0223 \mathrm{~min}^{-1}$.
\end{abstract}

\section{Introduction}

In recent years, research on the synthesis of nanoparticles using green materials, commonly called green synthesis, has been growing. The proposed materials are types of microorganisms, enzymes, plants, or plant extracts [1]. The reported biological resources can be used as a reducing and stabilizing agent in the synthesis of metal nanoparticles [2-5].

The role of plants in the synthesis of metal nanoparticles depends on the content of secondary metabolites. Specific plants contain specific chemical compounds which can act as active substances in the process of reduction and stabilization of nanoparticles. These compounds are alternative environmentally friendly materials in nanoparticle production due to their function to reduce the use of hazardous chemicals, including wastes [6]. Biomolecules in plant extracts that can reduce metal ions into nanoparticles include proteins, polysaccharides, alkaloids, flavonoids, terpenoids, and phenolic acids $[7,8]$.

Several studies of green synthesis have used the extracts of J. sambac leaf [5], Rosa rugosa leaf [9], Magnolia kobus and Diospyros kaki leaves [10], Ocimum sanctum leaf [11], Aerva lanata leaf [12], Coriandrum sativum leaf [13], Phyllanthus [14], and henna leaf [15] as reducing agents in AuNPs synthesis. On the other hand, Indonesia has abundant natural resources, including a biological diversity [16-19]. Many types of plants can be explored and used as a nanoparticles green synthesis material. One of the plants which is easily found in Indonesia and has not been reported as a nanoparticles synthesis material is Polyscias scutellaria. Polyscias scutellaria leaves contain alkaloids, saponins, flavonoids, and polyphenols [20]. Therefore, Polyscias scutellaria leaf is an appropriate choice as a reducing and stabilizing agent in green synthesis of AuNPs.

AuNPs are interesting to study, especially their catalytic properties [21-25], due to their excellent stability. They have been known as excellent catalysts in redox reactions due to their large surface area. In a previous study, AuNPs have been widely used as a good catalyst in reducing methylene blue (MB) in the presence of sodium borohydride $\left(\mathrm{NaBH}_{4}\right)$. The existence of AuNPs as a catalyst makes the reduction of $\mathrm{MB}$ run faster [26].

In this work, AuNPs were synthesized using Polyscias scutellaria leaf extract (PSE) with the assistance of UV 
radiation. Moreover, reduction of $\mathrm{MB}$ was used as a model reaction to evaluate the catalytic activity of AuNPs.

\section{Experimental}

2.1. Chemicals and Materials. Polyscias scutellaria was obtained from Tegalwaru, Bogor, and has been determined at LIPI, Bogor, West Java, Indonesia. $\mathrm{NaBH}_{4}$ and methylene blue were obtained from Merck. Methanol, n-hexane, and ethyl acetate were obtained from PT. Brataco. $\mathrm{HAuCl}_{4}$ solution used in this research was synthesized by dissolving $99.99 \%$ of pure Au metal (PT Antam) in aqua regia $\left(\mathrm{HNO}_{3}: \mathrm{HCl}=1: 3\right)$ solution. All chemicals were of analytical grade and were used without further purification. MilliQ water $\left(18.2 \Omega \mathrm{cm}^{-1}\right)$ was used to make aqueous solutions.

2.2. Preparation of Polyscias scutellaria Leaf Extract. Five kilograms of Polyscias scutellaria leaves was washed with water and dried in the open air. $50 \mathrm{~g}$ of dried Polyscias scutellaria leaf powder was macerated in $250 \mathrm{~mL}$ of methanol for 7 days. The mixture was filtered to obtain a greenish concentrated solution. It was partitioned using $n$-hexane with the volume ratio of $1: 1$. The methanol fraction was collected and concentrated using a vacuum rotatory evaporator at $50^{\circ} \mathrm{C}$. It was repartitioned using water and ethyl acetate solvents in a volume ratio of $1: 1$. The final water fraction of Polyscias scutellaria leaf extract (PSE) was then collected and concentrated using a vacuum rotatory evaporator. The water fraction of PSE was tested phytochemically and characterized using FTIR spectroscopy (Prestige 21, Shimadzu) to determine the content of secondary metabolites for the synthesis of AuNPs.

2.3. Synthesis of $A u$ Nanoparticles. Nine millilitres of 1.0 $\times 10^{-4} \mathrm{M} \mathrm{HAuCl}_{4}$ solution was added to $1.0 \mathrm{~mL}$ of water fraction of PSE with various concentrations from 0.001 to $0.050 \%(\mathrm{~m} / \mathrm{v})$. Each mixture was irradiated under a UV lamp for 2 hours. The synthesis results were characterized using a UV-Vis spectrophotometer (Shimadzu 2600), FTIR, particle size analyzer (PSA, Malvern ZEN 1600), XRD (Shimadzu 7000), and TEM-SAED (JEM 1400).

2.4. Catalytic Activity of AuNPs. The mixture of $4.0 \mathrm{~mL}$ of $3.0 \times 10^{-5} \mathrm{M}$ methylene blue and $0.5 \mathrm{~mL}$ of $0.1 \mathrm{M} \mathrm{NaBH}_{4}$ solution was added to AuNPs colloid as a catalyst at various volumes of $50-150 \mu \mathrm{L}$ or equivalent to the concentration of $1.10-3.23 \%(\mathrm{v} / \mathrm{v})$. The mixture was shaken and its reaction was observed through absorbance change using a UV-Vis spectrophotometer against reaction time for 30 minutes.

\section{Results and Discussion}

3.1. Identification of Polyscias scutellaria Leaf Extract. Aqueous and methanol leaf extracts of Polyscias scutellaria (PSE) were phytochemically tested to determine its active compounds. The methanol fraction showed a positive result of flavonoids, steroids, alkaloids, and saponins, whereas the

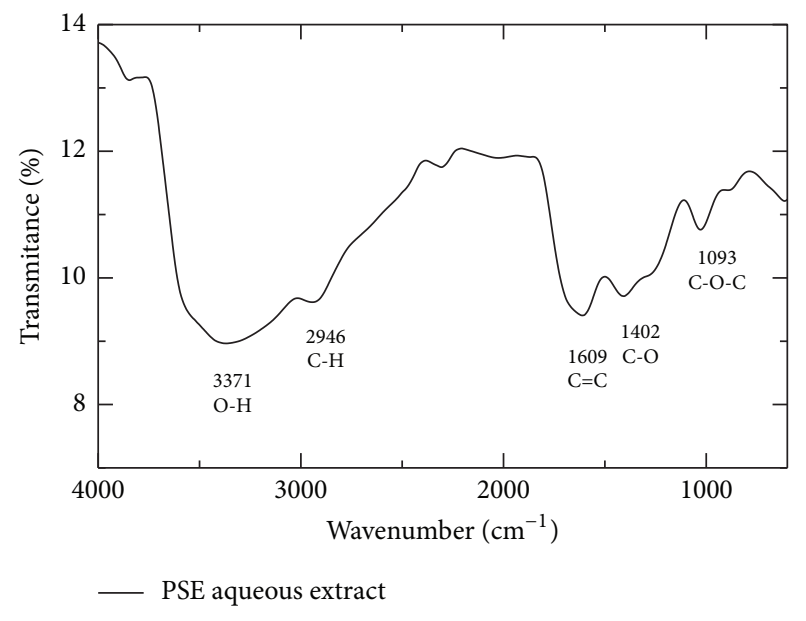

FIgURE 1: FTIR spectrum of PSE aqueous extract.

aqueous fraction showed a positive result of flavonoids, alkaloids, and saponins.

FTIR characterization was conducted to determine the functional groups of PSE aqueous fraction as shown in Figure 1. The stretch of -OH group was observed at wavenumber $3371 \mathrm{~cm}^{-1}, \mathrm{C}-\mathrm{H}$ group at $2946 \mathrm{~cm}^{-1}, \mathrm{C}=\mathrm{C}$ aromatic group at $1609 \mathrm{~cm}^{-1}$, -C-O aromatic ring at $1402 \mathrm{~cm}^{-1}$, and C-O$\mathrm{C}$ group at $1093 \mathrm{~cm}^{-1}$. These results are consistent with the flavonoids FTIR character of Sesbania grandiflora leaf extract from Das and Velusamy's research in 2014 [26]. Therefore, the active compound in the aqueous PSE indicated a type of flavonoid compounds.

3.2. PSE Concentration Effect in AuNPs Synthesis. AuNPs were synthesized using PSE under UV radiation for 2 hours due to containing less active compounds at room conditions. Therefore, the higher energy of UV light is required to excite the electrons in the active compound for reducing $\mathrm{Au}^{3+}$ to $\mathrm{Au}^{0}$. AuNPs formation was observed through the color changes from yellow to pink at $\lambda_{\max }$ of $510-580 \mathrm{~nm}$ [27]. AuNPs synthesis was conducted in various concentrations of PSE to determine the optimum concentration for reducing and stabilizing AuNPs. The higher the concentration of PSE, the more intense the color of the colloid generated in the system, due to the increase of the reducing agent. However, in high concentrations of PSE, faster growth of AuNPs core occurred, causing an increase in the nanoparticles collisions frequency to form agglomeration.

The optimum concentration of PSE in AuNPs synthesis was indicated from the high absorbance value, smallest maximum wavelength $\left(\lambda_{\max }\right)$, and sharpest peak shape. Absorbance indicates the amount of substance to absorb light. Wavelength indicates the amount of energy needed by nanoparticles to conduct surface plasmon resonance (SPR). The great size of nanoparticles results in a smaller bandgap. Therefore, the energy required to conduct electronic transition was getting smaller and $\lambda_{\text {max }}$ shifted towards a higher value. Sharp absorption peaks indicate that the 


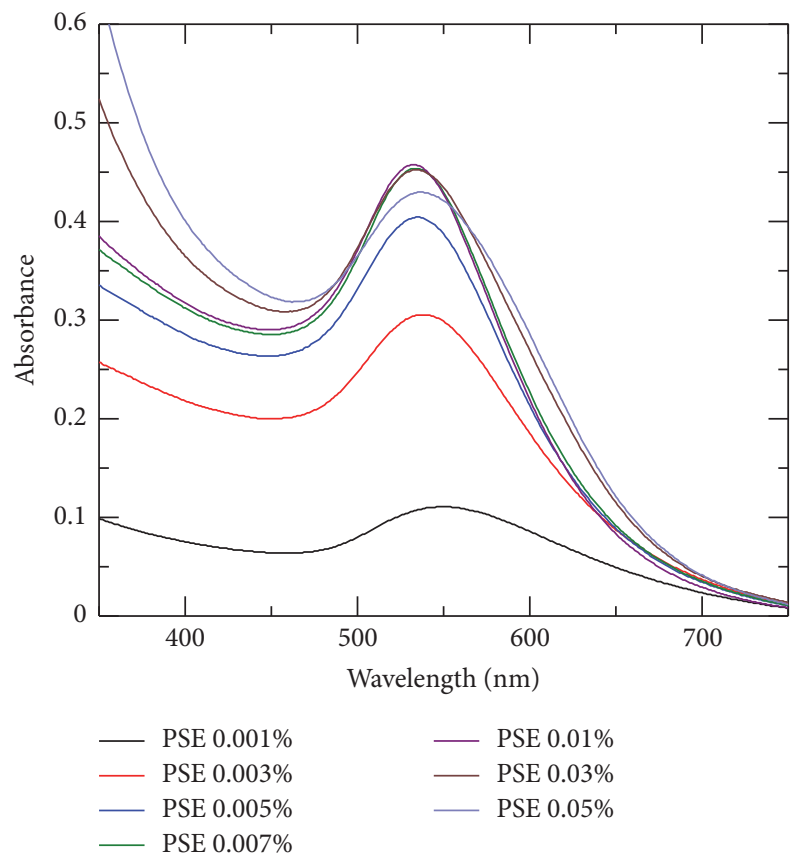

Figure 2: UV-Vis absorption spectra of AuNPs formation with PSE concentrations of 0.001 to $0.05 \%(\mathrm{w} / \mathrm{v})$.

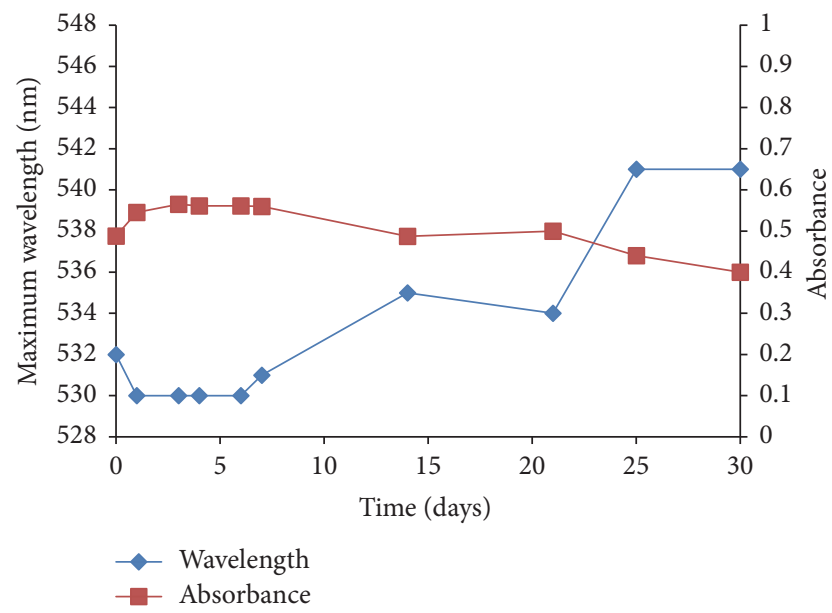

FIgURE 3: AuNPs stability at PSE concentration of $0.01 \%$ observed for 30 days.

formed nanoparticles have a homogeneous size. The UVVis absorption spectra of AuNPs formation against various PSE concentrations are shown in Figure 2. The optimum concentration of PSE in AuNPs synthesis was $0.01 \%(w / v)$, and AuNPs had a good stability for 21 days observed at $\lambda_{\text {max }}$ of $532-534 \mathrm{~nm}$ as shown in Figure 3. The observation of stability after 21 days showed larger $\lambda_{\max }$ shift and a significant decrease of absorbance, indicating the occurrence of agglomeration [28].

3.3. Particle Size Analysis. PSA characterization was conducted to determine the particle size and size distribution of AuNPs as shown in Figure 4. AuNPs size was distributed in

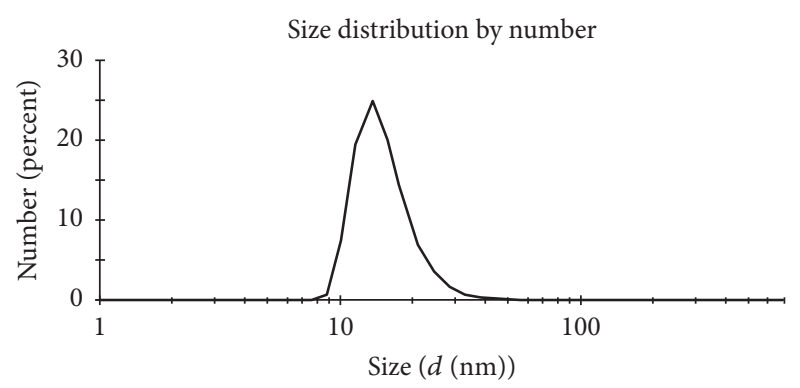

FIgure 4: Particle size distribution analysis of AuNPs at 0.01\% PSE concentration.

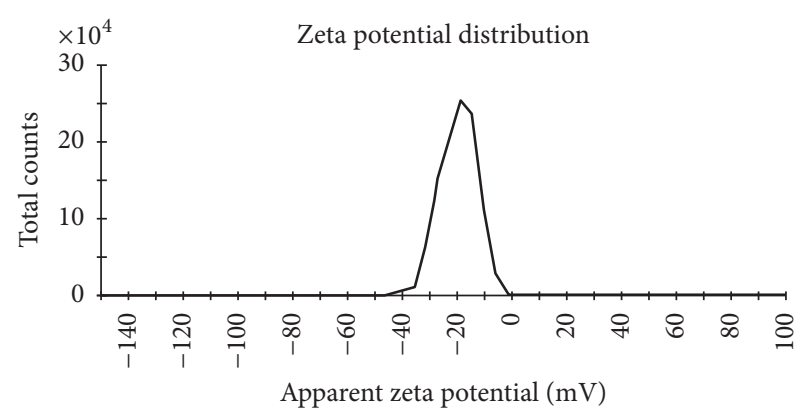

FIGURE 5: Zeta potential distribution analysis of AuNPs at 0.01\% PSE concentration.

a single peak, $15.49 \mathrm{~nm}$. The resulting size indicated that the PSE had sufficient strength to reduce $\mathrm{Au}^{3+}$ to $\mathrm{Au}^{0}$. This was also confirmed from the zeta potential value of $-19.6 \mathrm{mV}$ that explained the charge of PSE stabilizer capped AuNPs surface (Figure 5). The more negative the zeta potential value, the more frequent the interparticle repulsion, so that the particle becomes more stable [29]. It is concluded that the PSE is a good stabilizing agent for AuNPs.

3.4. FTIR Analysis. FTIR characterization was conducted to investigate the interaction between functional groups of PSE and AuNPs in the PSE capped AuNPs. FTIR spectra show the wavenumber shift of PSE functional groups before and after AuNPs formation as shown in Figure 6. The vibrations of the -OH group shifted from 3371 to $3427 \mathrm{~cm}^{-1}$ and those of the $\mathrm{C}=\mathrm{C}$ aromatic group shifted from 1609 to $1634 \mathrm{~cm}^{-1}$. These small shifts are due to the interaction of functional groups $(-\mathrm{OH}$ and $\mathrm{C}=\mathrm{C})$ in PSE compounds on AuNPs surface. This indicates that AuNPs are capped by the flavonoids in PSE. The oxidation of flavonoids in aqueous solutions under UV light may produce keto forms and act as a reducing agent for $\mathrm{Au}^{3+}$ to $\mathrm{Au}^{0}[26,30]$.

3.5. TEM-SAED Analysis. TEM-SAED characterization was conducted to observe the morphology, particle size, and crystal structure of AuNPs. Figure 7 shows the TEM images of the synthesized particle with a magnification of 150,000x. The morphology of AuNPs was spheres with a diameter of 5-20 nm. It was in accordance with the result of PSA characterization. 


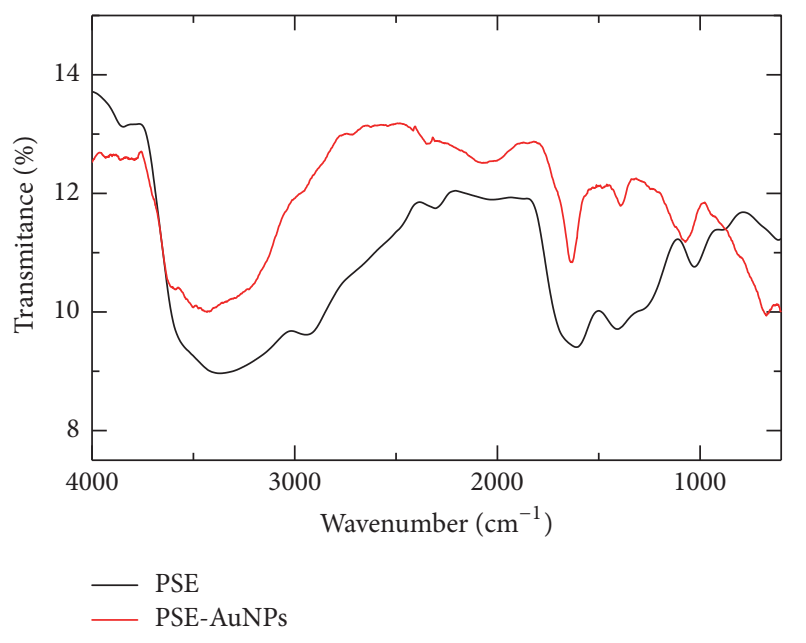

FIGURE 6: FTIR spectra of PSE and PSE capped AuNPs at 0.01\% PSE concentration.

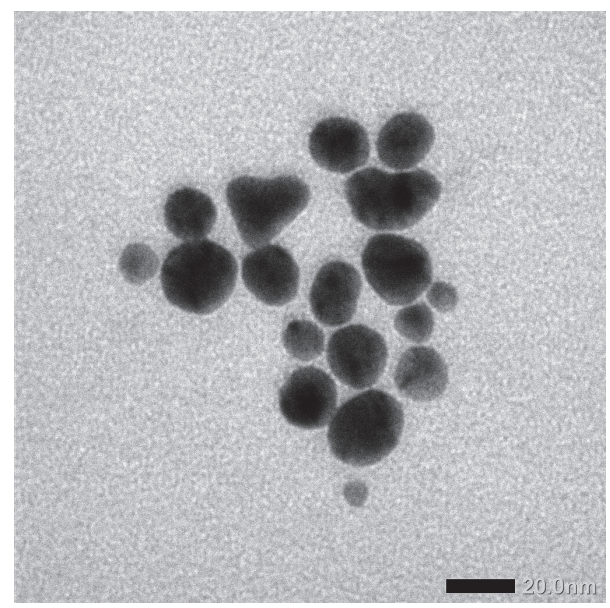

FIGURE 7: TEM images of synthesized AuNPs with a magnification of $150,000 x$.

To confirm AuNPs formation and its crystal phase, the Miller indices are adjusted with data join committee on powder diffraction standards of Au (JCPDS number 04-0748) by SAED analysis as shown in Figure 8 . The Miller indices were (111), (200), (220), (311), and (222), indicating that the synthesized AuNPs have a phase crystal of face centered cubic $[26,30,31]$.

3.6. XRD Analysis. XRD characterization was conducted to determine the crystallinity of AuNPs to support the data of TEM-SAED. Typical diffractogram peaks of AuNPs were determined by comparing the value of diffraction angle $(2 \theta)$ against JCPDS Au data as shown in Figure 9. From the results, there are some peaks of $2 \theta$ values: $38.013,44.190,64.448$, 77.418 , and $81.572^{\circ}$ matched with JCPDS Au number 040748: $38.184,44.392,64.576,77.547$, and 81.721 , respectively $[26,30,31]$.

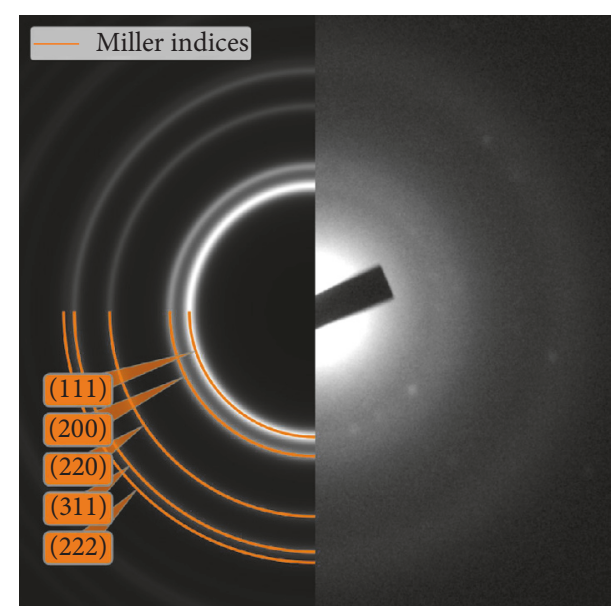

FIGURE 8: SAED pattern of the synthesized AuNPs.

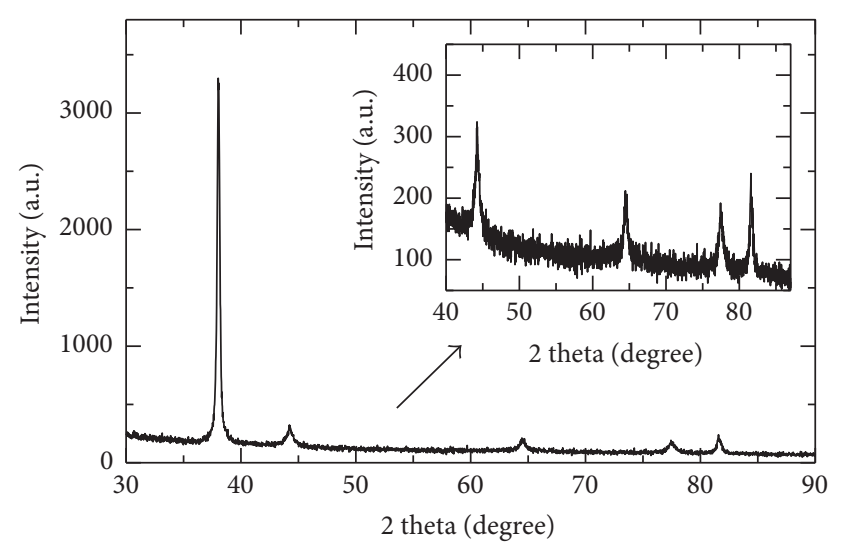

Figure 9: X-ray diffractogram of the synthesized AuNPs.

3.7. Catalytic Activity of AuNPs for the Methylene Blue Reduction. The catalytic activity of the synthesized AuNPs was tested in the reduction of methylene blue by $\mathrm{NaBH}_{4}$. Reduction of methylene blue was observed from the fading of blue color solution due to the decrease of UV-Vis absorption spectrum at $\lambda_{\max }$ of $664 \mathrm{~nm}[32,33]$. In comparison, in the same circumstances, methylene blue was reacted with $\mathrm{NaBH}_{4}$ in the absence of AuNPs catalyst and showed a very small decrease in absorbance of methylene blue as shown in Figure 10.

The reduction reaction was as follows:

$$
\begin{gathered}
4 \mathrm{C}_{16} \mathrm{H}_{18} \mathrm{~N}_{3} \mathrm{~S}+\mathrm{H}^{+}+\mathrm{BH}_{4}^{-}+3 \mathrm{H}_{2} \mathrm{O} \longrightarrow \\
4 \mathrm{C}_{16} \mathrm{H}_{20} \mathrm{~N}_{3} \mathrm{~S}+\mathrm{H}_{3} \mathrm{BO}_{3}
\end{gathered}
$$

The reaction was assumed to follow pseudo-first-order kinetics. It used the excess concentration of $\mathrm{NaBH}_{4}$ compared to the concentration of methylene blue, so the concentration of $\mathrm{NaBH}_{4}$ was considered to be fixed during the reaction. The pseudo-first-order rate constant was calculated from the 


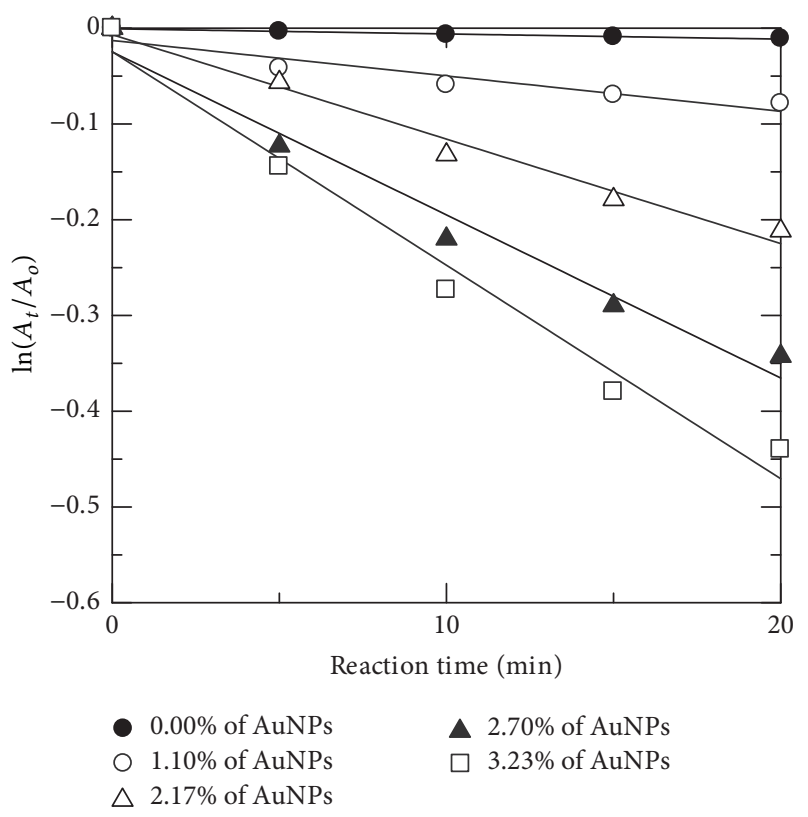

Figure 10: Plots of $\ln \left(A_{t} / A_{0}\right)$ versus reaction time with various concentrations of PSE-AuNPs.

slope of the linear line equation plotting $[31,34] \ln \left(C_{t} / C_{0}\right)$ versus time $(t)$ with a kinetic equation:

$$
\begin{aligned}
\frac{d C_{t}}{d t} & =-k C_{\mathrm{NaBH}_{4}} C_{t}=-k_{\mathrm{obs}} C_{t} \\
\ln \left(\frac{C_{t}}{C_{0}}\right) & =\ln \left(\frac{A_{t}}{A_{0}}\right)=-k_{\text {obs }} t .
\end{aligned}
$$

The plotting results of $\ln \left(A_{t} / A_{0}\right)$ versus reaction time $(t)$ in various concentrations of AuNPs are shown in Figure 10. Pseudo-first-order rate constants on AuNPs catalyst concentrations of $0.00,1.10,2.17,2.70$, and $3.23 \%$ were 0.00054 , $0.0037,0.0109,0.0170$, and $0.0223 \mathrm{~min}^{-1}$, respectively, with maximum reduction percent of methylene blue at $71.10 \%$. These results indicated that the synthesized AuNPs have a good catalytic activity to reduce methylene blue.

\section{Conclusion}

The AuNPs were successfully synthesized using a cheap and environmentally friendly route. PSE can be effectively used as reducing agent and stabilizer to produce AuNPs with diameters of 5-20 nm and stable for 21 days. The synthesized AuNPs were then used as a reduction catalyst of methylene blue in the presence of $\mathrm{NaBH}_{4}$. It was found that AuNPs are able to play a role as good catalysts with a pseudo-first-order rate constant of $0.0223 \mathrm{~min}^{-1}$. AuNPs synthesis through this green method can contribute to the other fields such as green photocatalyst, drug delivery, antimicroorganism, adsorbent, detector, and green separation science and technology.

\section{Conflicts of Interest}

The authors declare that they have no conflicts of interest.

\section{Acknowledgments}

This work was funded by Hibah PITTA 2016 from Universitas Indonesia through the directorate of research and community services, Universitas Indonesia (no. 2040/UN2.R12/ HKP.05.00/2016).

\section{References}

[1] P. Mohanpuria, N. K. Rana, and S. K. Yadav, "Biosynthesis of nanoparticles: technological concepts and future applications," Journal of Nanoparticle Research, vol. 10, no. 3, pp. 507-517, 2008.

[2] A. Rajan, A. R. Rajan, and D. Philip, "Elettaria cardamomum seed mediated rapid synthesis of gold nanoparticles and its biological activities," OpenNano, vol. 2, pp. 1-8, 2017.

[3] P. Singh, Y.-J. Kim, D. Zhang, and D.-C. Yang, "Biological synthesis of nanoparticles from plants and microorganisms," Trends in Biotechnology, vol. 34, no. 7, pp. 588-599, 2016.

[4] P. D. Shankar, S. Shobana, I. Karuppusamy et al., "A review on the biosynthesis of metallic nanoparticles (gold and silver) using bio-components of microalgae: Formation mechanism and applications," Enzyme and Microbial Technology, vol. 95, pp. 28-44, 2016.

[5] S. Yallappa, J. Manjanna, and B. L. Dhananjaya, "Phytosynthesis of stable Au, Ag and Au-Ag alloy nanoparticles using J. Sambac leaves extract, and their enhanced antimicrobial activity in presence of organic antimicrobials," Spectrochimica Acta Part A: Molecular and Biomolecular Spectroscopy, vol. 137, no. 1, pp. 236243, 2015.

[6] W. Handayani, C. Imawan, and S. Purbaningsih, "Potensi ekstrak beberapa jenis tumbuhan sebagai agen pereduksi untuk biosintesis nanopartikel perak," Seminar Nasional Biologi, pp. 558-567, 2010.

[7] P. Kuppusamy, M. M. Yusoff, G. P. Maniam, and N. Govindan, "Biosynthesis of metallic nanoparticles using plant derivatives and their new avenues in pharmacological applications-an updated report," Saudi Pharmaceutical Journal, vol. 24, pp. 473484, 2016.

[8] S. Iravani, "Green synthesis of metal nanoparticles using plants," Green Chemistry, vol. 13, no. 10, pp. 2638-2650, 2011.

[9] S. P. Dubey, M. Lahtinen, and M. Sillanpää, "Green synthesis and characterizations of silver and gold nanoparticles using leaf extract of Rosa rugosa," Colloids and Surfaces A: Physicochemical and Engineering Aspects, vol. 364, no. 1-3, pp. 34-41, 2010.

[10] J. Y. Song, H.-K. Jang, and B. S. Kim, "Biological synthesis of gold nanoparticles using Magnolia kobus and Diopyros kaki leaf extracts," Process Biochemistry, vol. 44, no. 10, pp. 1133-1138, 2009.

[11] D. Philip and C. Unni, "Extracellular biosynthesis of gold and silver nanoparticles using Krishna tulsi (Ocimum sanctum) leaf," Physica E: Low-Dimensional Systems and Nanostructures, vol. 43, no. 7, pp. 1318-1322, 2011.

[12] S. Joseph and B. Mathew, "Microwave assisted facile green synthesis of silver and gold nanocatalysts using the leaf extract of Aerva lanata," Spectrochimica Acta Part A: Molecular and Biomolecular Spectroscopy, vol. 136, pp. 1371-1379, 2015.

[13] K. B. Narayanan and N. Sakthivel, "Coriander leaf mediated biosynthesis of gold nanoparticles," Materials Letters, vol. 62, no. 30, pp. 4588-4590, 2008.

[14] J. Kasthuri, K. Kathiravan, and N. Rajendiran, "Phyllanthinassisted biosynthesis of silver and gold nanoparticles: a novel 
biological approach," Journal of Nanoparticle Research, vol. 11, no. 5, pp. 1075-1085, 2009.

[15] J. Kasthuri, S. Veerapandian, and N. Rajendiran, "Biological synthesis of silver and gold nanoparticles using apiin as reducing agent," Colloids and Surfaces B: Biointerfaces, vol. 68, no. 1, pp. 55-60, 2009.

[16] N. Andarwulan, R. Batari, D. A. Sandrasari, B. Bolling, and H. Wijaya, "Flavonoid content and antioxidant activity of vegetables from Indonesia," Food Chemistry, vol. 121, no. 4, pp. 1231-1235, 2010.

[17] E. Suhartono, E. Viani, M. A. Rahmadhan, I. S. Gultom, M. F. Rakhman, and D. Indrawardhana, "Total flavonoid and antioxidant activity of some selected medicinal plants in South Kalimantan of Indonesian," APCBEE Procedia, vol. 4, pp. 235239, 2012.

[18] Elfahmi, H. J. Woerdenbag, and O. Kayser, "Jamu: indonesian traditional herbal medicine towards rational phytopharmacological use," Journal of Herbal Medicine, vol. 4, no. 2, pp. 51-73, 2014.

[19] S. Sukrasno, D. L. Aulifa, Y. Karlina, and N. P. Aryantha, "Antiphytophthora and antifusarium from Indonesian medicinal plants," Asian Journal of Pharmaceutical Sciences, vol. 11, no. 1, pp. 28-29, 2016.

[20] R. Batari, "Identifikasi senyawa flavonoid pada sayuran indigenous Jawa Barat," Food Science and Technology, 2007, http://repository.ipb.ac.id/handle/123456789/11947.

[21] S. Maity, I. Kumar Sen, and S. Sirajul Islam, "Green synthesis of gold nanoparticles using gum polysaccharide of Cochlospermum religiosum (katira gum) and study of catalytic activity," Physica E: Low-dimensional Systems and Nanostructures, vol. 45, pp. 130-134, 2012.

[22] J. Zeng, Q. Zhang, J. Chen, and Y. Xia, "A comparison study of the catalytic properties of Au-based nanocages, nanoboxes, and nanoparticles," Nano Letters, vol. 10, no. 1, pp. 30-35, 2010.

[23] S. Wunder, Y. Lu, M. Albrecht, and M. Ballauff, "Catalytic activity of faceted gold nanoparticles studied by a model reaction: evidence for substrate-induced surface restructuring," ACS Catalysis, vol. 1, no. 8, pp. 908-916, 2011.

[24] A. Corma and H. Garcia, "Supported gold nanoparticles as catalysts for organic reactions," Chemical Society Reviews, vol. 37, no. 9, pp. 2096-2126, 2008.

[25] S. Panigrahi, S. Basu, S. Praharaj et al., "Synthesis and sizeselective catalysis by supported gold nanoparticles: study on heterogeneous and homogeneous catalytic process," The Journal of Physical Chemistry C, vol. 111, no. 12, pp. 4596-4605, 2007.

[26] J. Das and P. Velusamy, "Catalytic reduction of methylene blue using biogenic gold nanoparticles from Sesbania grandiflora L," Journal of the Taiwan Institute of Chemical Engineers, vol. 45, no. 5, pp. 2280-2285, 2014.

[27] P. Daizy, "Green synthesis of gold and silver nanoparticles using Hibiscus rosa sinensis," Physica E: Low-dimensional Systems and Nanostructures, vol. 42, no. 5, pp. 1417-1424, 2010.

[28] Y. Yulizar, H. A. Ariyanta, and L. Abduracman, "Green synthesis of gold nanoparticles using aqueous garlic (Allium sativum L.) Extract, and its interaction study with melamine," Bulletin of Chemical Reaction Engineering \& Catalysis, vol. 12, no. 2, pp. 212-218, 2017.

[29] L. H. Bac, J. S. Kim, and J. C. Kim, "Size, Optical and stability properties of gold nanoparticles synthesized by electrical explosion of wire in different aqueous media," Reviews on Advanced Materials Science, vol. 28, pp. 117-121, 2011.
[30] S. P. Dubey, M. Lahtinen, H. Särkkä, and M. Sillanpää, "Bioprospective of Sorbus aucuparia leaf extract in development of silver and gold nanocolloids," Colloids and Surfaces B: Biointerfaces, vol. 80, no. 1, pp. 26-33, 2010.

[31] Y. Yulizar, G. T. M. Kadja, and M. Safaat, "Well-exposed gold nanoclusters on Indonesia natural zeolite: a highly active and reusable catalyst for the reduction of p-nitrophenol," Reaction Kinetics, Mechanisms and Catalysis, vol. 117, no. 1, pp. 353-363, 2016.

[32] V. S. Suvith and D. Philip, "Catalytic degradation of methylene blue using biosynthesized gold and silver nanoparticles," Spectrochimica Acta Part A: Molecular and Biomolecular Spectroscopy, vol. 118, pp. 526-532, 2014.

[33] A. U. Khan, Q. Yuan, Y. Wei et al., "Photocatalytic and antibacterial response of biosynthesized gold nanoparticles," Journal of Photochemistry and Photobiology B: Biology, vol. 162, pp. 273277, 2016.

[34] H. A. Ariyanta and Y. Yulizar, "The shape conversion of silver nanoparticles through heating and its application as homogeneous catalyst in reduction of 4- nitrophenol," IOP Conference Series: Materials Science and Engineering, vol. 107, Article ID 012002, 2016. 

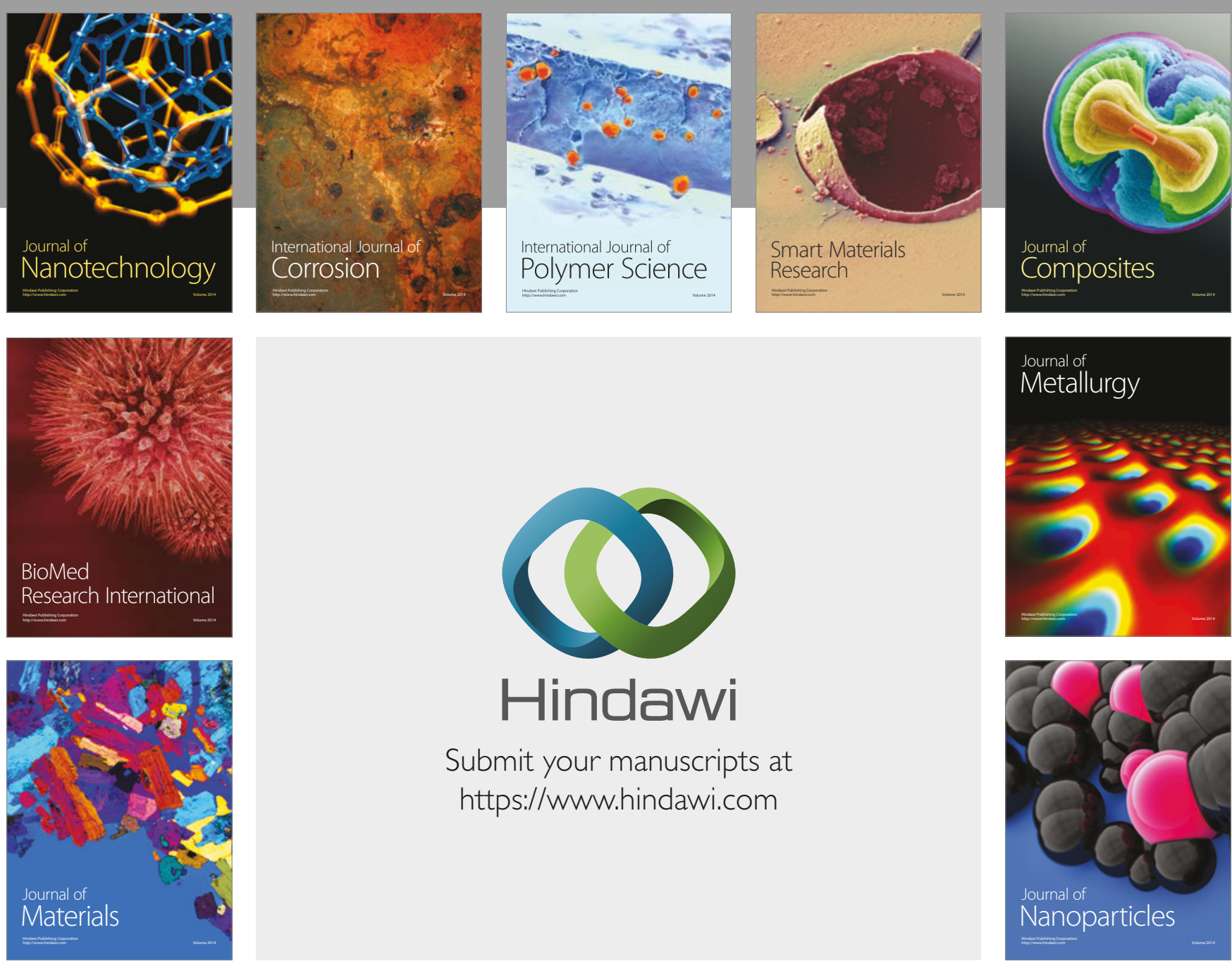

\section{Hindawi}

Submit your manuscripts at

https://www.hindawi.com
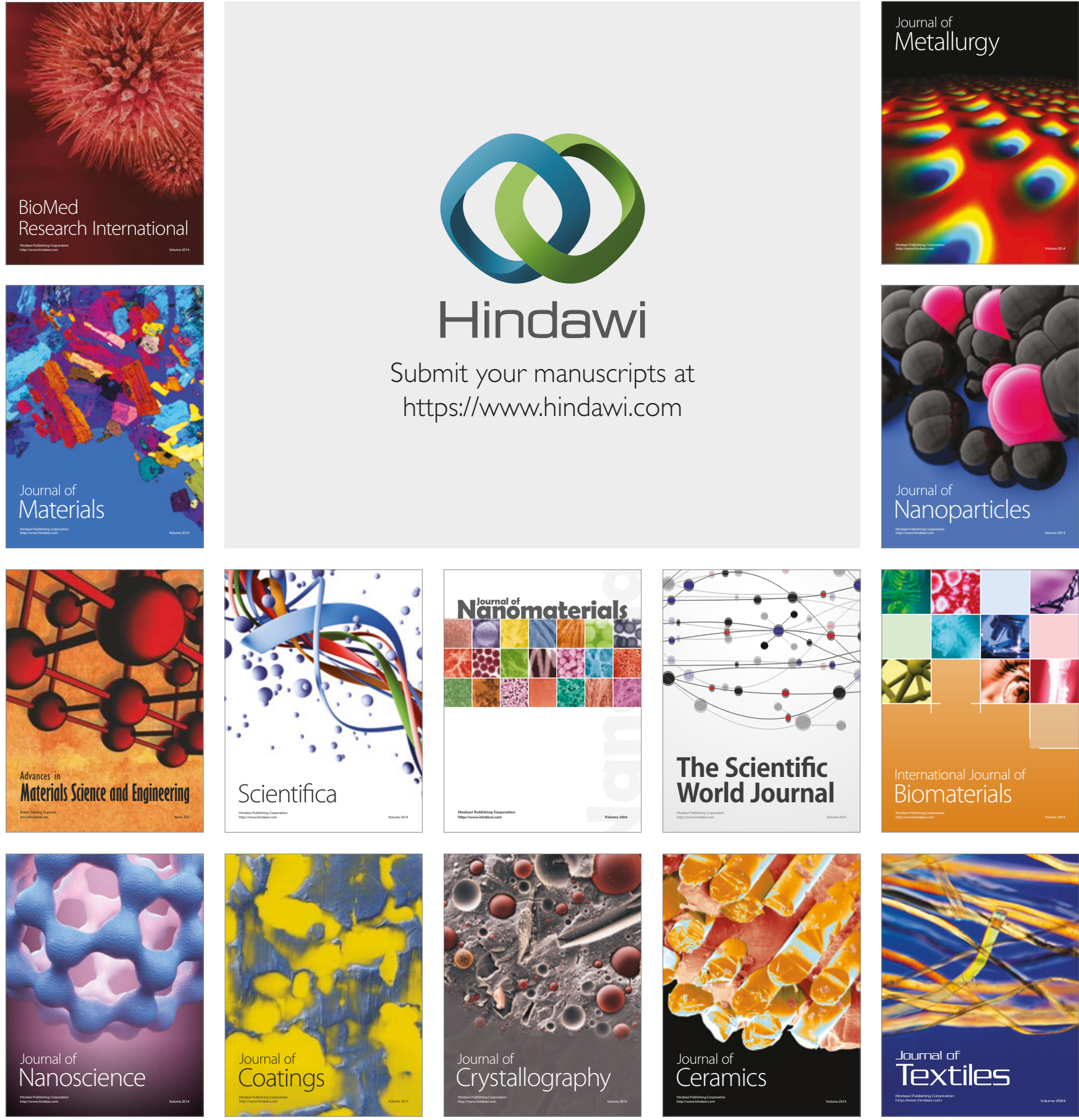

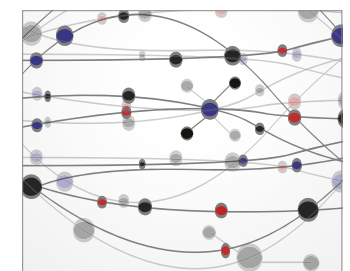

The Scientific World Journal
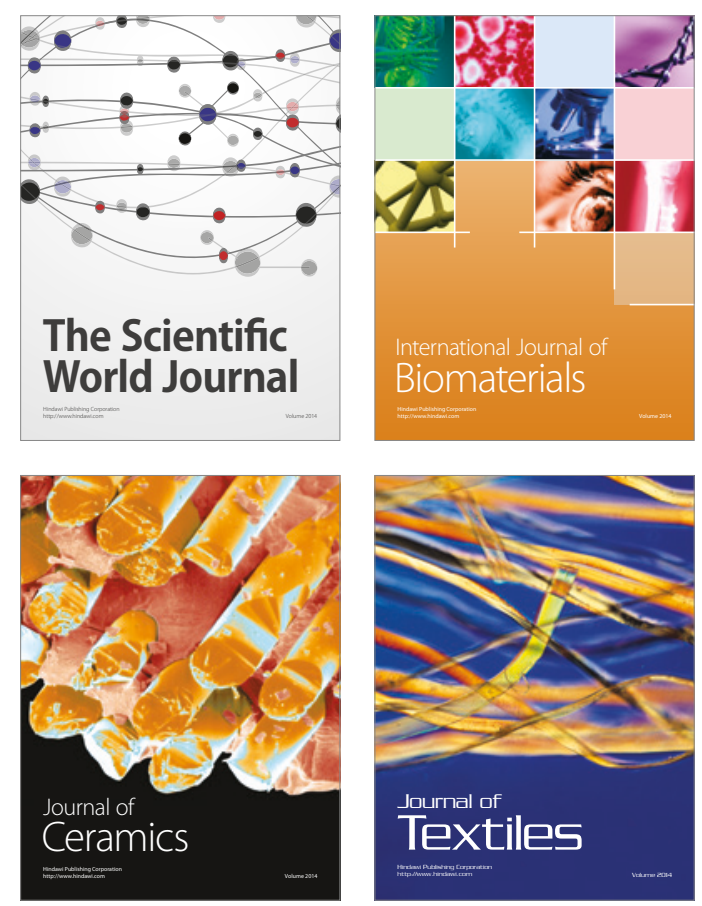